\title{
Prevalence and characteristics of mouse mammary tumor virus-like virus associated breast cancer in China
}

Fa-liang Wang ${ }^{1 *} \mathbb{D}$, Xiao-li Zhang ${ }^{2}$, Ming Yang ${ }^{1}$, Jun Lin ${ }^{3}$, Yong-fang Yue ${ }^{4}$, Ya-dan Li ${ }^{5}$, Xian Wang ${ }^{5}$, Qiang Shu ${ }^{1,6^{*}}$ and Hong-chuan Jin $^{5^{*}}$

\begin{abstract}
Background: Despite extensive molecular epidemiological studies, the prevalence and characteristics of Mouse Mammary Tumor Virus-Like Virus (MMTV-LV) in Chinese women breast cancer are still unclear. Besides, the prevalence of MMTV-LV in women breast cancer tissue varies in different countries and its dependent factors remain inconclusive.

Methods: In the first part of the study, a case-control study was performed. 119 breast cancer samples (84 from Northern China and 35 from Southern China) and 50 breast fibroadenoma specimens were collected from Chinese women patients. MMTV-like env sequence and the homology to MMTV env gene were analysed by semi-nested polymerase chain reaction (PCR). We also explored the association of MMTV-LV prevalence with sample sources (Southern and Northern China) and patients' clinicopathological characteristics. To investigate the dependent factors of the prevalence of MMTV-LV in breast cancer worldwide, a meta-analysis was conducted in the second part of the study.

Results: We found that the prevalence of MMTV-LV was much higher in breast cancer tissues (17.65\%) than that in breast fibroadenoma specimens $(4.00 \%)(P<0.05)$. MMTV-LV prevalence in Chinese women breast cancer tissues was significantly different between Southern China $(5.71 \%)$ and Northern China $(22.62 \%)(P<0.05)$. The prevalence of MMTV-LV also associates significantly with expression of HER2, but shows no significant correlation with other parameters. In the meta-analysis, we found that MMTV-LV prevalence in breast cancer tissue was dependent on the distribution of M. domesticus mouse (M. d), M. musculus mouse (M.m) and M.castaneus mouse (M.c) worldwide $(P<0.05)$.
\end{abstract}

\footnotetext{
* Correspondence: 21118179@zju.edu.cn; shuqiang@zju.edu.cn; jinhc@zju.edu.cn

1Department of Surgical Oncology, The Children's Hospital, Zhejiang University School of Medicine, National Clinical Research Center for Child Health, Binsheng Road 3333, Hangzhou 310052, China

${ }^{5}$ Laboratory of Cancer Biology, Department of Medical Oncology, Key lab of Biotherapy in Zhejiang, Sir Run Run Shaw Hospital, School of Medicine, Zhejiang University, East Qingchun Road 3, Hangzhou 310000, China

Full list of author information is available at the end of the article
}

(c) The Author(s). 2021 Open Access This article is licensed under a Creative Commons Attribution 4.0 International License, which permits use, sharing, adaptation, distribution and reproduction in any medium or format, as long as you give appropriate credit to the original author(s) and the source, provide a link to the Creative Commons licence, and indicate if changes were made. The images or other third party material in this article are included in the article's Creative Commons licence, unless indicated otherwise in a credit line to the material. If material is not included in the article's Creative Commons licence and your intended use is not permitted by statutory regulation or exceeds the permitted use, you will need to obtain permission directly from the copyright holder. To view a copy of this licence, visit http://creativecommons.org/licenses/by/4.0/ The Creative Commons Public Domain Dedication waiver (http://creativecommons.org/publicdomain/zero/1.0/) applies to the data made available in this article, unless otherwise stated in a credit line to the data. 
Conclusion: The distribution of house mice may be a crucial environmental factor that explains the geographic differences in human breast cancer incidence. Our findings may provide a potential avenue of prevention, diagnosis and treatment for breast cancer.

Keywords: Mouse mammary tumor virus-like virus (MMTV-LV), Breast cancer, M. domesticus mouse, M.musculus mouse, M.castaneus mouse

\section{Introduction}

Breast carcinoma is a leading cause of cancer mortality in women worldwide. Many risk factors have been identified in the development of this tumor, such as diet, obesity, nulliparity, hormones, increased life expectancy and family history [1-6]. However, the etiology and molecular mechanism of breast carcinogenesis remain inconclusive despite decades of research [7, 8].

Increasing evidence suggests that viral infection may play a key role in the pathogenesis of breast cancer [9]. As early as 1936, John Bittner discovered the "mouse milk factor" that could increase the incidence of mouse breast cancer [10]. The "factor" was proved to be the mouse mammary tumor virus (MMTV) in the subsequent studies [11-13]. Subsequently, MMTV-like antigens and viral particles were successively detected in human milk and cancer cells during the 1970s and 1980s [14, 15]. In the recent several years, studies using PCR method with primers from selected regions of the MMTV env gene screened MMTV-like sequences in human milk [13] and breast cancer specimens [16-23]. Up to now, various investigators have postulated that mouse mammary tumor virus-like virus (MMTV-LV), a similar virus to MMTV, might be a cause for human breast cancer [24-27].

MMTV-LV prevalence in human breast cancer varies with geographical location. In recent studies, MMTV-LV prevalence was $30-40 \%$ in breast cancer tissues from several Western and North Africa countries including America, Italy, Mexico, Australia, Argentina and Tunisia $[16,17,19,24,25,28-45]$. In East and Southeast Asia, where breast cancer incidence is known to be low, the presence of MMTV-LV sequences in breast cancer tissues is $16.79 \%$ in China [46]; while the ratio is 0.62 and $1.72 \%$ in Vietnam and Myanmar respectively [34, 47].

House mice, the carriers of MMTV, also distribute differently all over the world. Sage et al. divided them into three subspecies, namely M. domesticus (M.d), M.musculus (M.m) and M.castaneus (M.c) [48]. M. d mice originally landed from North Africa to Western Europe, and subsequently migrated to America, Australia, New Zealand and Hawaii via ships sailing from western European ports. While M. m mice distribute along with the range of M. d from Central Europe to East Asia and M.c settles from Southern China to central Iran $[48,49]$. The ability to transmit MMTV varies in the three species of house mice due to the different copy number of MMTV in these mice [49].

It's still unclear whether MMTV-LV has been transferred to humans from mice. If so, the prevalence of MMTV-LV in human breast cancer should be correlated with the distribution of house mice. Accordingly, the prevalence of MMTV-LV in breast cancer should be different between Southern and Northern China, and vary in countries with different house mice distribution.

In this study, we firstly evaluated the different prevalence of MMTV-LV in human breast cancer in Southern and Northern China using a case-control study. And then we analyzed the possible association between the presence of MMTV-LV sequences and various Clinicopathological parameters. Finally, we pooled all the data related to MMTV-LV prevalence in breast cancer worldwide together and conducted meta-analysis and metaregression to assess the effect of house mouse distribution on MMTV-LV prevalence.

\section{Materials and methods \\ Case-control study \\ Patients and specimens}

Paraffin embedded formalin fixed tissues from 169 Chinese women (119 breast cancer patients and 50 breast fibroadenoma patients) were obtained from samples collected between 2005 and 2019 in the Department of Pathology at the Second People's Hospital of Jiande and the First Affiliated Hospital of Hebei North University, which locate in Southern and Northern China, respectively. Since the project was a retrospective study and used the remaining clinical samples, informed consent was exempted. The ethical issues were approved by Medical Ethics Committee of the Second People's Hospital of Jiande (Supplementary Fig. 1). 35 breast cancer samples were collected from Chinese women who lived in Southern China, and the other 84 breast cancer samples were from Northern China. WHO criterias were adopted in histopathological diagnosis of each tumor [50]. The distribution of tumors was as follows: 107 invasive ductal carcinoma, 9 invasive lobular carcinoma and 3 mucous adenocarcinoma. According to the modified Scarff-Bloom-Richardson (SBR) system, invasive ductal carcinomas were graded into three grades [51]. The clinicopathological characters of the patients were summarized in Table 1. 
Table 1 Clinicopathological characteristics of breast cancer patients

\begin{tabular}{ll}
\hline Variable & Number of cases (\%) \\
\hline Total & 119 \\
Age (years) & \\
$<35$ & $3(2.52)$ \\
$35-50$ & $59(49.58)$ \\
$>50$ & $57(47.90)$ \\
Sample source (province) & \\
Hebei & $84(70.59)$ \\
Zhejiang & $35(29.41)$ \\
Histological type & \\
Invasive ductal carcinoma & $107(89.92)$ \\
Invasive lobular carcinoma & $9(7.56)$ \\
Mucious Adenocarcinoma & $3(2.52)$ \\
Histological grade ${ }^{\text {a }}$ & \\
Grade I & $48(40.34)$ \\
Grade II & $49(41.18)$ \\
Grade III & $10(8.40)$ \\
Lymph node involvement & \\
Negative & $60(50.42)$ \\
Positive & $59(49.58)$ \\
\hline
\end{tabular}

${ }^{a}$ Histological grade was performed only in specimens with invasive ductal carcinoma

\section{$D N A$ extractions and $P C R$}

Formalin fixed paraffin embedded tissue were scraped from paraffin blocks using Ultra-Thin Semiautomatic Microtome and transferred to $1.5 \mathrm{ml}$ eppendorf tubes using bamboo sticks. To avoid cross contamination, bamboo sticks were used for each paraffin block. TIANamp Genomic DNA Kit was used to extract genomic DNA. The sections scraped were deparaffinized in $1 \mathrm{ml}$ xylene and centrifuged at $12,000 \mathrm{~g}$ for $3 \mathrm{~min}$. After repeating this step twice, the sections were immersed twice in $1 \mathrm{ml}$ absolute ethanol to remove xylene. Other steps were according to the manufacturer's instructions. DNA from breast cell lines of MCF7, Bcap37, MDAMB-231and MDA-MB-453 were also extracted using the TIANamp Genomic DNA Kit under the manufacturer's guidance.

The semi-nested PCR method with excellent sensitivity, specificity and simplicity was adopted to detection of MMTV env gene-like sequences [37]. $200 \mathrm{ng}$ of genomic DNA was used as template in the firststage of PCR with outer primers J948-env-F (5'CCTCACTGCCAGATCGCCTT-3') and J950-env-R $\left(5^{\prime}\right.$-CAGGTAGCAGCACATATGGC-3') to amplify a $601 \mathrm{bp}$ DNA fragment. 2ul of the first-stage product was used in the second round PCR as template with the primer pair J948-env-F and J1011-env-R1 (5'-
CCTGCTTCATACCATCGATGAACC-3'), amplifying a $254 \mathrm{bp}$ inner sequence (Table 2 and Fig. 2A).

All PCR amplifications were carried out in a $30 \mu \mathrm{l} \mathrm{re-}$ action system containing $200 \mathrm{mM}$ of each dNTP, $0.2 \mu \mathrm{M}$ of each forward and reverse primers, $1 \mathrm{U}$ DNA polymerase, $50 \mathrm{mM} \mathrm{KCl}, 10 \mathrm{mM}$ Tris- $\mathrm{HCl}(\mathrm{pH} \mathrm{8.4})$ and $1.5 \mathrm{mM}$ $\mathrm{MgCl}_{2}$. Thermocycling was carried out in thermal circulator by denaturing at $94{ }^{\circ} \mathrm{C}$ for $5 \mathrm{~min}$, then 35 circles (denaturing at $94{ }^{\circ} \mathrm{C}$ for $35 \mathrm{~s}$, annealing at $52^{\circ} \mathrm{C}$ for $30 \mathrm{~s}$, extending at $72{ }^{\circ} \mathrm{C}$ for $40 \mathrm{~s}$ ), and finally extending at $72{ }^{\circ} \mathrm{C}$ for $10 \mathrm{~min}$. The reproducibility of the PCR reactions was confirmed in triplicate.

Before detecting the DNA samples from patients, ordinary PCR with primers J948-env-F and J950-env-R was carried out on the DNA from breast carcinoma cell lines MCF7, Bcap37, MDA-MB-231 and MDA-MB-453. MMTV-like env gene sequences were positive in Bcap37 and MDA-MB-453 (Fig. 1C), so we treated DNA from Bcap37 cells as positive control. Negative controls were reactions without adding DNA template. In order to confirm the existence of viral DNA and exclude the amplification of non-specific or endogenous retroviral sequences, twelve randomly selected positive PCR products were purified and sequenced.

\section{Immunohistochemical staining and analysis}

The expression of Estrogen receptor (ER), Progesterone receptor (PR), and HER2 was detected using immunohistochemistry method. The immunohistochemical staining was interpreted by the same experienced pathologist according to the American Society of Clinical Oncology and College of American Pathologists guidelines, who did not know any other clinicopathological or molecular information. For ER and PR, if $10 \%$ or more tumor cells show nuclear staining, the case is considered positive. The HER2 expression was estimated and scored on a scale of 0 to $3+$ according to the membrane staining pattern [52].

\section{Data analysis}

MMTV-LV prevalence in tumors was analyzed for possible association with clinicopathological parameters (age, sample source, histological grade and type, lymph node status and tumor positions) and the expression of receptors (ER, PR and HER2) using $X^{2}$ or Fisher's test

Table 2 Primer sequences and location in the MMTV env gene

\begin{tabular}{lll}
\hline Designation & Sequence(5'-3') & Location \\
\hline J948-env-F & CCTCACTGCCAGATCGCCTT & 6048-6067 \\
J950-env-R & CAGGTAGCAGCACATATGGC & $6629-6648$ \\
J1011-env-R1 & CCTGCTTCATACCATCGATGAACC & 6278-6301 \\
IDD428-GAPDH-F & GGAGTCAACGGATTTGT & \\
IDD429-GAPDH-R & GTGATGGGATTCCATTGAT & \\
\hline
\end{tabular}



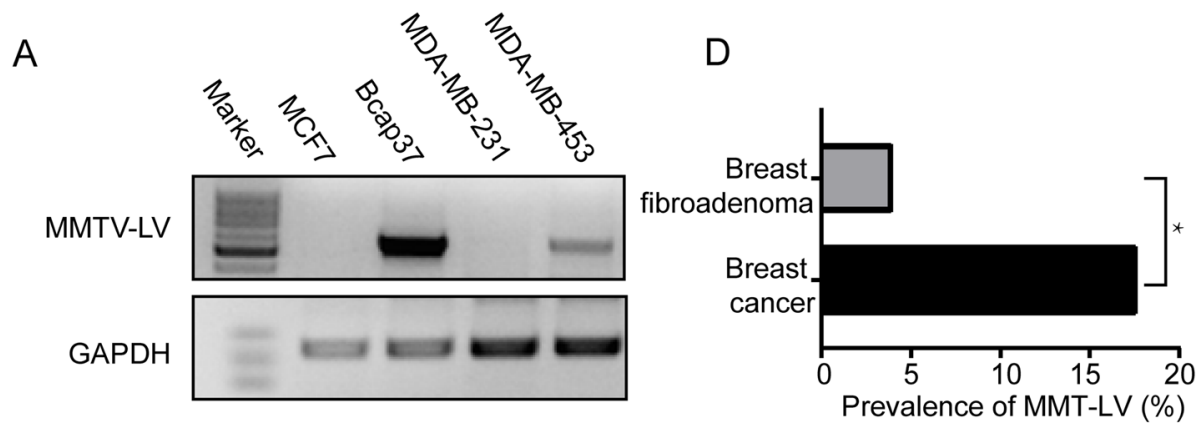

B $\begin{array}{llllllllllllllllllll}M & \mathrm{P} & \mathrm{N} & 65 & 66 & 67 & 68 & 69 & 70 & 71 & 72 & 73 & 74 & 75 & 76 & 77 & 78 & 79 & 80 & \mathrm{M}\end{array}$

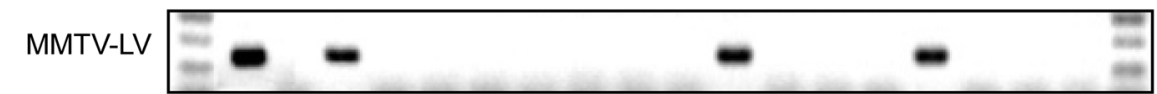

GAPDH

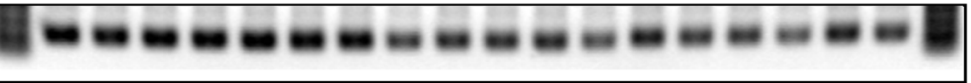

C

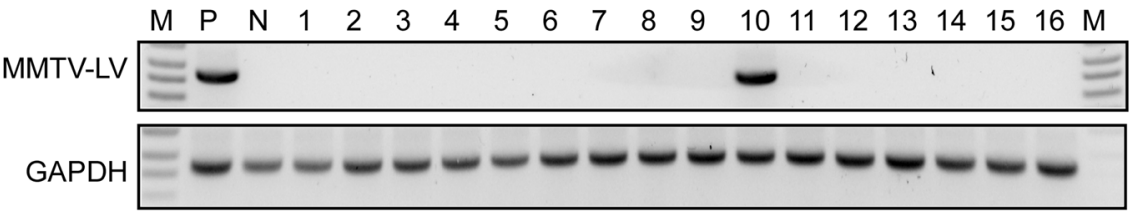

Fig. 1 Detection of MMTV-LV sequence in breast cancer. 1.5\% agarose gel electrophoresis of the GelRed-stained amplification products for MMTV-LV gene screening using a semi-nested PCR assays. A. breast cancer cell lines $\mathbf{B}$. breast cancer specimens $\mathbf{C}$. breast fibroadenoma tissues $\mathbf{D}$. Prevalence of MMTV-like env sequence in Chinese women breast cancer specimens compared to Chinese women breast fibroadenoma tissues (based on Table 3) *Indicating the significant difference between groups for $P<0.05$

with SPSS 20.0. If $P$ value was less than 0.05 , the comparison between groups was considered statistically significant. DNA similarity alignments were performed using DNAMAN 8.0 software.

\section{Systematic review and meta-analysis \\ Search strategy}

A comprehensive search of PubMed, Google Scholar, Web of Science and EBSCO (ASP/BSP) was done to find publications reported between January 1995 and May 2020 using the $\mathrm{MeSH}$ terms and key words "mouse mammary tumor virus", "MMTV" "Human" and "breast cancer or breast carcinoma". We also evaluated the relevant references cited in retrieved articles.

\section{Eligibility criteria}

Studies were included according to the following criteria: (i) Studies had to use PCR method to screen MMTV-LV sequence in specimens. Researches were excluded if their PCR product not homologous to MMTV [53]. (ii) Researches only focusing on breast cancer cell line [42] and mice breast tumors [54] were not included. (iii) If data was published in more than one study, only the publication with the most explicit description was included. The article selection process applied in this meta-analysis was illustrated in Fig. 4.

\section{Data extraction}

Two investigators (Fa-liang Wang and Ming Yang) independently extracted data according to the terms and reached consensus for each trial. The following information was recorded: first author's name, country of origin, sample size, MMTV-LV prevalence in breast carcinoma tissues. The information of all included studies was summarized in Table 5.

\section{Meta-analysis}

The meta-analysis consists of two parts. In the first part, we pooled the MMTV-LV infection rates in breast carcinoma reported in previous publications and this study. In the second part, we analyzed the correlation between MMTV-LV prevalence in human breast cancer and the distribution of different types of house mice in a global map (Supplementary Fig. 2) in a meta-regression model.

In the meta-analysis, Cochrane $x^{2}$ test was performed to examine the null hypothesis that the observed heterogeneity was random and the degree of heterogeneity was estimated using the statistic $I^{2}=[(\mathrm{Q}-d f) / \mathrm{Q}] \times 100 \%(\mathrm{Q}=$ Cochrane $x^{2}, d f=$ degrees of freedom). Due to the 
significant heterogeneity in this study, the DerSimonian and Laird method was adopted to pool the data in a random-effect model [61].

To determine the influence of the distribution of house mice on the prevalence of MMTV-LV in human breast cancer tissue, we performed a random-effects meta-regression. The proportion of heterogeneity attributable to distribution of house mice was estimated by comparing the between-studies component of variance in the null model $\left(\tau_{0}{ }^{2}\right)$ with the estimate of $\tau^{2}$ for the model with the covariate of house mice distribution $\left[\left(\mathrm{\tau}_{0}{ }^{2}-\mathrm{\tau}^{2}\right) / \mathrm{\tau}_{0}{ }^{2}\right] . P$ values of $<0.05$ suggested that the factor involved in the meta-regression could partly explain the heterogeneity in the meta-analysis.

The publication bias was quantitatively assessed in Egger's test [62]. When $P$ value was less than 0.1 , the publication bias was considered present. For other tests, $P$ values of $<0.05$ were considered statistically significant. The meta-analysis was carried out in STATA 12.0.

\section{Results}

\section{Screening of MMTV-like env gene sequence in breast} tumor DNA

The MMTV-like env gene sequence was screened in the genomic DNA from 119 breast cancer specimens, 50 breast fibroadenoma specimens and 4 human breast cancer cell lines. The house keeping gene GAPDH was amplified to confirm the integrity of all DNA samples. In the 119 breast cancer specimens, the PCR products of expected size were successfully amplified from 21 specimens. While in the 50 breast fibroadenoma tissues, only 2 samples were identified containing the sequence. Moreover, the sequence could also be detected in 2 cell lines, including Bcap37 and MDA-MB-453 (Fig. 1).

\section{Sequence homology analysis of the PCR products}

To analyse the homology of PCR products to MMTV env gene, twelve PCR products randomly chosen from different specimens were sequenced. The sequence homology of the PCR products was $98-99 \%$ to the MMTV env sequence from the GeneBank (AF346816) (Figs. 2B and 3). So we reasoned that all of the specimens with PCR products were infected by MMTV-LV.

\section{Prevalence of MMTV-LV and its correlation with clinicopathological characteristics of patients}

Consistent with our hypothesis, the positive rate of MMTV-LV env sequence was significantly correlated with sample sources (Southern China 5.71\%, and Northern China 22.62\%, $P=0.03$ ).

The association between MMTV-LV prevalence and the clinical properties of the specimens was further analyzed with statistical approaches. We found that the prevalence of MMTV-LV env sequence in breast cancer tissues (17.65\%) was much higher than that in breast fibroadenoma specimens $(4.00 \%)$, with a $P$-value of 0.02 . (Fig. 1D and Table 3). What's more, the presence of MMTV-LV env sequence was significantly correlated with HER-2 expression in breast cancer tissues (Table 4). The proportion of samples with high HER-2 expression in MMTV-LV positive tissues (71.43\%) was much higher than that in MMTV-LV negative tissues (43.88\%) (Table $4, P=0.02)$. No significant correlations were observed with the age of the patients, histological types, histological grades, lymph node status, tumor position, ER and PR expression in breast cancer tissues.

\section{Meta-analysis of MMTV-LV prevalence in breast cancer patients}

As shown in Fig. 4, database searching identified 1012 records and a review of reference lists uncovered 56

A

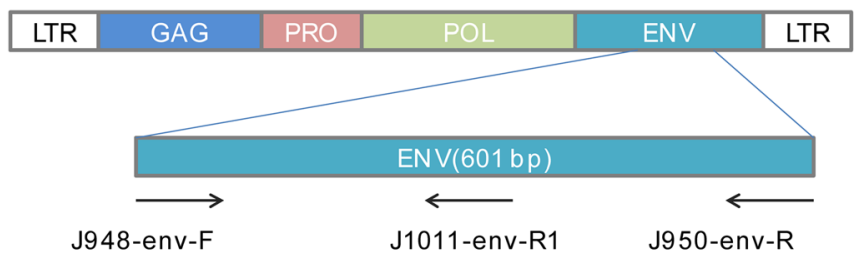

B

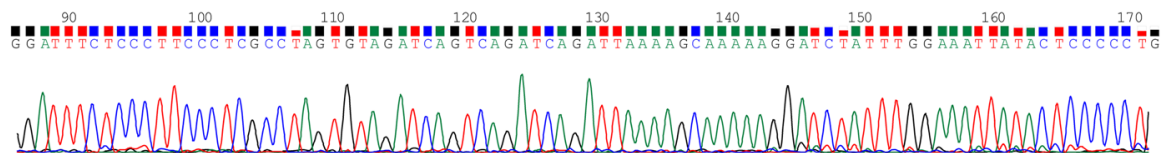

Fig. 2 MMTV genome and the position of the primers. A. The outer primers used in the primary PCR were J948-env-F and J950-env-R. The inner primers used in the secondary PCR were J948-env-F and J1011-env-R1. All the primers were shown by arrows. B. DNA sequence of the MMTV-like env PCR product 


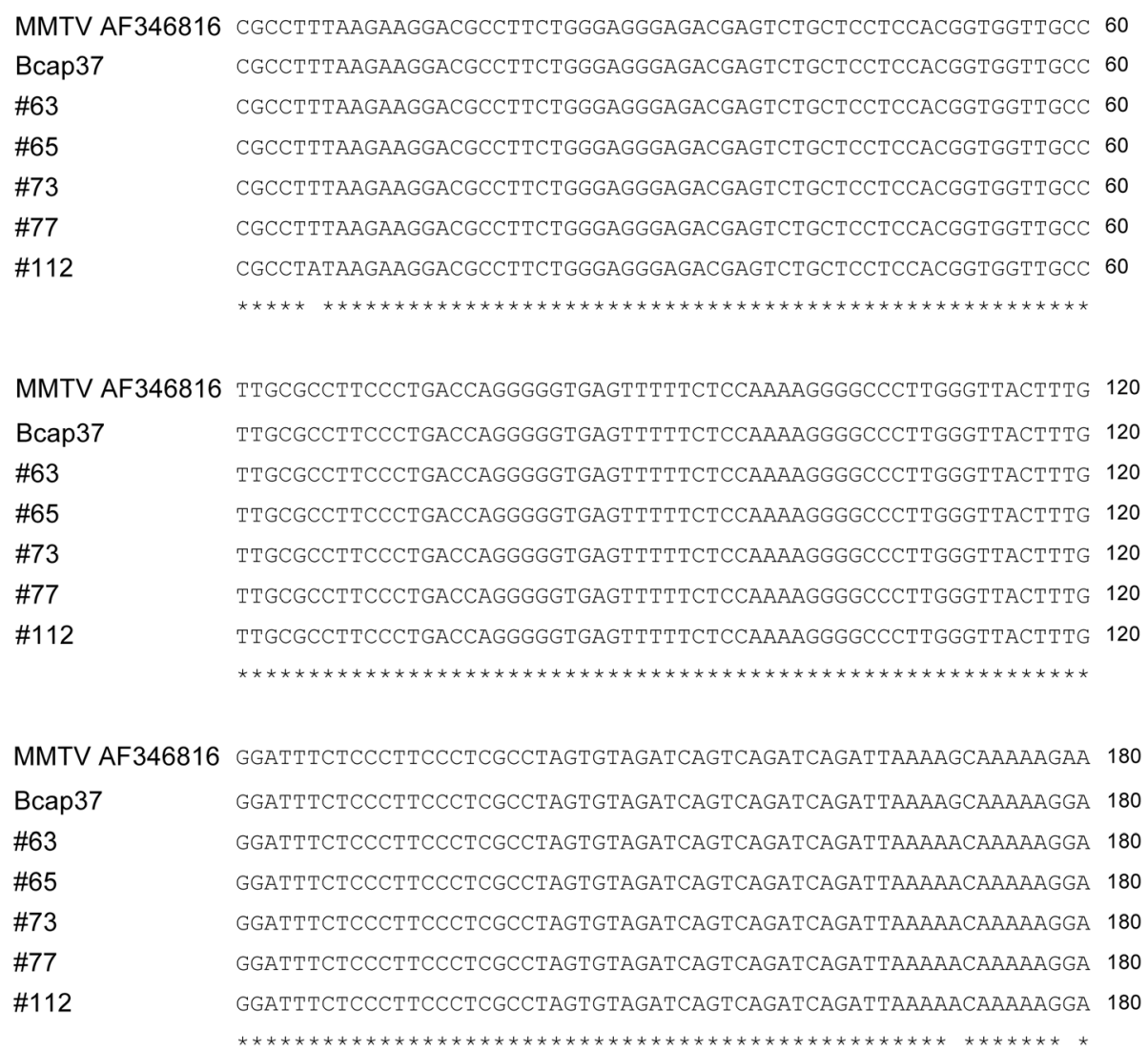

MMTV AF346816 TCTATTTGGAAATTATACTCCCCCTGTCAATAAAGAGGTTC 221

Bcap37 TCTATTTGGAATTATACTCCCCCTGTCAATAAAGAGGTTC 221

\#63 TCTATTTGGTAATTATACTCCCCCTGTCAATAAAGAGGTTC 221

\#65 TCTATTTGGAATTATACTCCCCCTGTCAATAAAGAGGTTC 221

\#73 TCTATTTGGAATTATACTCCCCCTGTCAATAAAGAGGTTC 221

\#77 TCTATTTGGAAATTATACTCCCCCTGTCAATAAAG--GTTC 221

\#112 TCTATTTGGTAATTATACTCCCCCTGTCAATAAAGAGGTTC 221

Fig. 3 Multiple nucleotide alignment of the sequences of PCR products (marked by their respective numbers) with MMTV env sequences retrieved from GenBank database (No. AF346816). Sequences were aligned using DNAMAN, version 8. Stars show conserved sites along the alignment

additional records. After removing duplicate studies, 742 records remained, 664 of which were excluded after reviewing titles and abstracts. In the remaining 78 articles, 13 reviews were excluded. 65 records underwent full text review, and 33 studies met the inclusion criteria $[20,22,46,47,55-57]$. We also included the data in the above case-control study, which was divided into two data sets according to the sample sources (Hebei and Zhejiang), so there were 35 data sets in total (Table 5). A publication bias test was performed before the studies were pooled together. The result revealed no obvious publication bias $(P=0.499)$.

According to the distribution of house mice [48, 49], we divided all the studies into three categories: M.c,

Table 3 Prevalence of MMTLV in breast cancer and breast fibroadenoma in Chinese women

\begin{tabular}{lllr}
\hline Histopathological type & Number of MMTV-LV positive cases & Number of MMTV-LV negative cases $^{P}$-value \\
\hline Breast cancer (\%) & $21(17.65)$ & $98(82.35)$ \\
Breast fibroadenoma (\%) & $2(4.00)$ & $48(96.00)$ & $\mathbf{0 . 0 2}$ \\
\hline
\end{tabular}

${ }^{a} P$ value was calculated by $\mathrm{X} 2$ (two sided) and was considered to statistically significant for $P<0.05$. Bold values indicate significant correlation 
Table 4 Characteristics of MMTLV positive and negative breast cancer in Chinese women

\begin{tabular}{|c|c|c|c|}
\hline Variables & Number of MMTLV positive cases (\%) & Number of MMTLV negative cases (\%) & $P$-value ${ }^{a}$ \\
\hline Ages (years) & & & 0.68 \\
\hline$<35$ & $0(0.00)$ & $3(3.06)$ & \\
\hline $35-50$ & $10(47.62)$ & $49(50.00)$ & \\
\hline$>50$ & $11(52.38)$ & $46(46.94)$ & \\
\hline Sample source (province) & & & 0.03 \\
\hline Northern China & $19(90.48)$ & $65(66.33)$ & \\
\hline Southern China & $2(9.52)$ & $33(33.67)$ & \\
\hline Histological type & & & 0.61 \\
\hline Invasive ductal carcinoma & $20(95.24)$ & 87 (88.78) & \\
\hline Invasive lobular carcinoma & $1(4.76)$ & $8(8.16)$ & \\
\hline Mucious Adenocarcinoma & $0(0.00)$ & $3(3.06)$ & \\
\hline Histological grade ${ }^{b}$ & & & 0.77 \\
\hline Gradel & $8(38.10)$ & $40(46.51)$ & \\
\hline Gradell & $11(52.38)$ & $38(44.19)$ & \\
\hline Gradelll & $2(9.52)$ & $8(9.30)$ & \\
\hline Lymph node involvement & & & 0.21 \\
\hline Positive & $8(38.10)$ & $52(53.06)$ & \\
\hline Negative & $13(61.90)$ & $46(46.94)$ & \\
\hline Position & & & 0.82 \\
\hline Right & $13(61.90)$ & $58(59.18)$ & \\
\hline Left & $8(38.10)$ & $40(40.82)$ & \\
\hline Estrogen receptor & & & 0.73 \\
\hline Positive & $12(57.14)$ & $52(53.06)$ & \\
\hline Negative & $9(42.86)$ & $46(46.94)$ & \\
\hline Progesterone receptor & & & 0.54 \\
\hline Positive & $12(57.14)$ & $63(64.29)$ & \\
\hline Negative & $9(42.86)$ & $35(35.71)$ & \\
\hline HER-2 & & & 0.02 \\
\hline$-/ 1+$ & $6(28.57)$ & $55(56.12)$ & \\
\hline $2+/ 3+$ & $15(71.43)$ & $43(43.88)$ & \\
\hline
\end{tabular}

a $P$ value was calculated by $\mathrm{X} 2$ or Fisher's tests and was considered to be statistically significant for $P<0.05$. Bold values indicate significant correlation

${ }^{\mathrm{b}}$ Histological grade was performed only in specimens with invasive ductal carcinoma

M.m and M.d, which were numbered 1, 2 and 3, respectively. The characteristics of the included studies are summarized in Table 5. All the studies were regionbased, in particular, 7 studies were based in M.c region (one data set from our case-control study) [20, 22, 47, 55-57], one study was based in M.c/M.m mixed region [46], one study was based in M.m region (our casecontrol study), and 26 studies were based in M.d region $[16,17,19,21,23-25,28-31,33-44,58-60]$.

MMTV-LV prevalence ranged from 1 to $78 \%$ in breast carcinoma tissue and the overall positive rate was 33\% (95\%CI: $26-$ $40 \%)$. There was a statistically significant heterogeneity between the included studies $\left(I^{2}=97.8 \%\right.$, Cochran's $Q$ test: $\left.P<0.05\right)$. In the subgroup analysis, it was found that MMTV-LV prevalence was lowest in M.c region (14, 95\%CI: 6-23\%) and highest in M.d region (39, 95\%CI, 31-46\%). There were statistically significant differences between the subgroups $(P<0.05)$ (Fig. 5).

To confirm the effect of house mice distribution on MMTV-LV prevalence, a meta-regression analysis was performed. The analysis result demonstrated that $27.31 \%$ variance between studies coming from different countries could be explained by the distribution of house mice, which was a crucial factor that affected the prevalence of MMTV-LV significantly $(P<0.05)$ (Fig. 6).

\section{Discussion}

Since the role and mechanism of viruses on cancer development were proposed in the 1970s and 1980s, there 


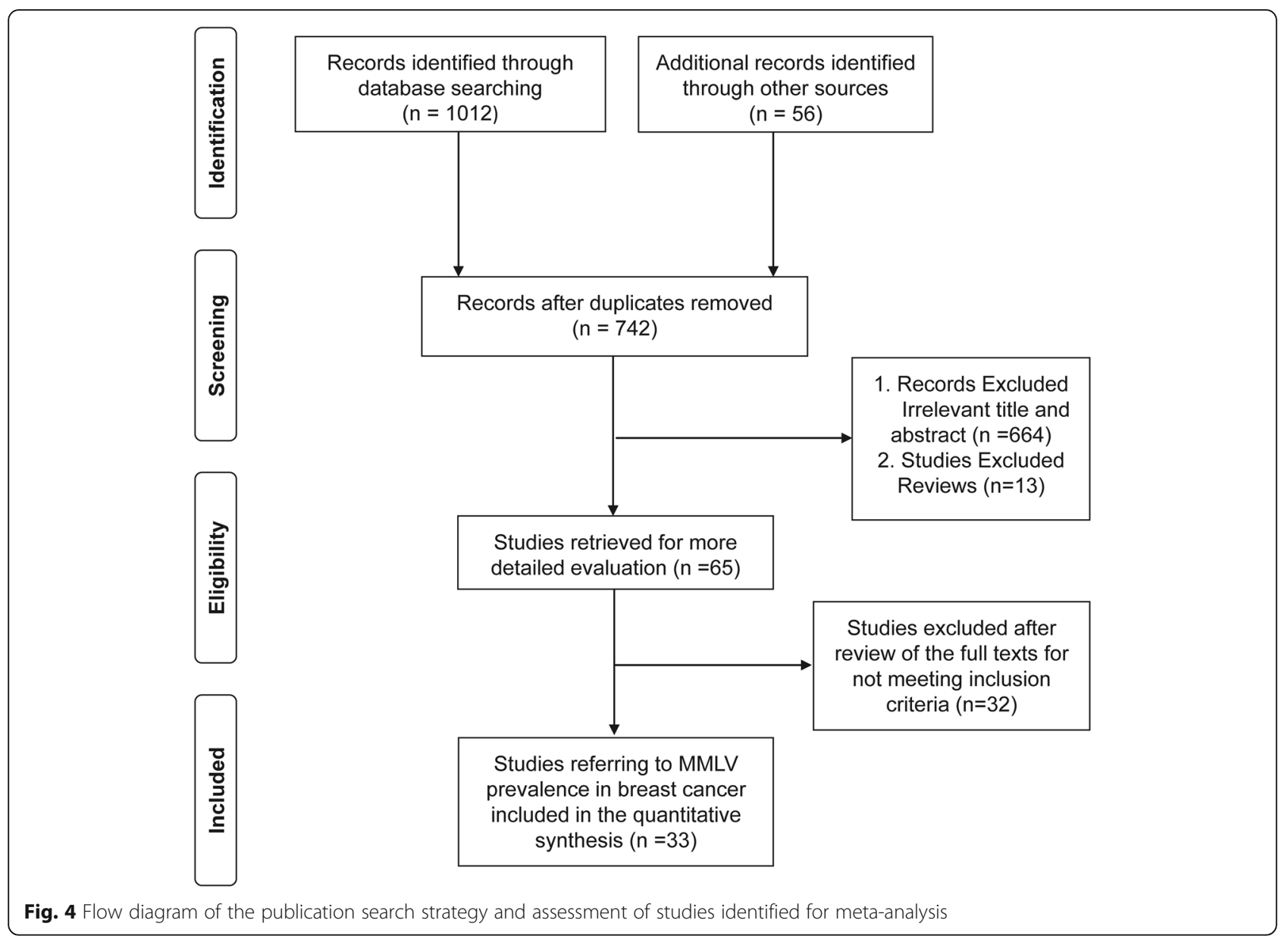

has been an avalanche of studies on the correlation between MMTV-LV and human breast carcinogenicity. Closely following the findings, studies discovered MMTV-like antigens or viral particles in human breast or breast cancer cells. Beyond that, immune responses to MMTV-LV antigens had also been detected in women with breast cancer [63-65]. However, some MMTV-LV sequence screening studies unexpectedly revealed that the detected DNA was highly homologous to human endogenous retrovirus (HERV), thereby hindering the development of related studies [66]. Until recent decades, the widespread application of PCR technology allows scientists to use primers from selected regions of genes with low homology to known HERV to detect MMTV-like DNA sequences in human breast cancer tissues [28]. Therefore, renewed interest in the viral etiology of breast cancer has been aroused.

In the first part of our study, we screened MMTV-LV env sequence in Chinese women breast cancer tissues, breast fibroadenoma specimens and human breast cancer cell lines. Except for several random mutations, the sequences of the PCR products showed $98-99 \%$ homology with the MMTV env sequence (Fig. 3). This signifies that house mouse, an important carrier of MMTV, may be a zoonotic source of MMTV-LV in human breast tumor. As a supportive argument for early human exposure, Stewart et al. [49] indicated that mouse fecal particles contaminated the stored grains, so the MMTV might enter the human digestive tract and then infected humans. In addition, cats might be infected with MMTV carried by mice and then spread the virus to humans [67]. Moreover, MMTV can also transmit through saliva inter-human [68]. MMTV-LV was ever found in the breast cancer tissues of father, mother and daughter, suggesting the possibility of MMTV-LV as an etiological agent which is related to familial breast cancer [69].

In the case-control study, the results indicated that the prevalence of MMTV-LV in breast cancer specimens (17.65\%) was much higher than that in breast fibroadenoma tissues (4\%) (Fig. 1D and Table 3), implying that infection of MMTV-LV may play an important role in breast carcinogenesis.

The long terminal repeat (LTR) sequence of MMTV was found to contain all the enhancer and promoter elements. Proviral DNA can integrate into the vicinity of 
Table 5 Studies included for the meta-analysis

\begin{tabular}{|c|c|c|c|c|c|}
\hline First Author & Year & Region & MMTV-LV Prevalence & Mouse species & Reference \\
\hline Wang FL & 2020 & China (South) & $2 / 35(5.71 \%)$ & M.c (1) & - \\
\hline Reza MA & 2015 & Iran & $12 / 100(12.00 \%)$ & M.c (1) & {$[55]$} \\
\hline San TH & 2017 & Myanmar & $1 / 58(1.72 \%)$ & M.c (1) & [47] \\
\hline Naushad W & 2017 & Pakistan & $83 / 250(33.20 \%)$ & M.c (1) & {$[22]$} \\
\hline Ford CE & 2004 & Vietnam & 1/161 (0.62\%) & M.c (1) & {$[56]$} \\
\hline Naushad W & 2014 & Pakistan & $16 / 80(20.00 \%)$ & M.c (1) & {$[20]$} \\
\hline Shariatpanahi S & 2017 & Iran & 19/59 (32.20\%) & M.c (1) & [57] \\
\hline Luo T & 2006 & China & 22/131 (16.79\%) & M.c/M.m (1.5) & {$[46]$} \\
\hline Wang FL & 2020 & China (Nouth) & 19/84 (22.62\%) & M.m (2) & - \\
\hline Nartey $\mathrm{T}$ & 2017 & Australia & $9 / 25(36.002 \%)$ & M.d (3) & {$[58]$} \\
\hline Wang $Y$ & 2001 & America & 188/495 (37.98\%) & M.d (3) & [31] \\
\hline Nazar AMA & 2014 & Iraqi & 22/38 (57.89\%) & M.d (3) & [59] \\
\hline Lawson JS & 2006 & Australia & $21 / 59$ (35.59\%) & M.d (3) & {$[40]$} \\
\hline Melana SM & 2002 & Argentine & 23/74 (31.08\%) & M.d (3) & {$[33]$} \\
\hline Lawson JS & 2018 & Australia & $12 / 45$ (26.67\%) & M.d (3) & [21] \\
\hline Lawson JS & 2004 & Australia & 20/42 (47.62\%) & M.d (3) & {$[38]$} \\
\hline Wang $Y$ & 2003 & America & 196/513 (38.21\%) & M.d (3) & {$[35]$} \\
\hline Ford CE & 2003 & Australia & 19/45 (42.22\%) & M.d (3) & {$[34]$} \\
\hline Zapata-Benavides P & 2007 & Mexico & $5 / 119$ (4.20\%) & M.d (3) & {$[42]$} \\
\hline Lawson JS & 2010 & Australia & $33 / 74$ (44.59\%) & M.d (3) & [44] \\
\hline Mok MT & 2008 & Australia & $28 / 50(56.00 \%)$ & M.d (3) & {$[19]$} \\
\hline Glenn WK & 2012 & Australia & $39 / 50(78.00 \%)$ & M.d (3) & [24] \\
\hline Levine PH & 2004 & Tunisia & 28/38 (73.68\%) & M.d (3) & [39] \\
\hline Melana SM & 2001 & Argentine & $32 / 106(30.19 \%)$ & M.d (3) & {$[16]$} \\
\hline Etkind PR & 2004 & America & 6/12 (50.00\%) & M.d (3) & {$[36]$} \\
\hline Faedo M & 2004 & Australia & $50 / 128(39.06 \%)$ & M.d (3) & {$[37]$} \\
\hline Ford CE & 2004 & Australia & 45/144 (31.25\%) & M.d (3) & [17] \\
\hline Mazzanti CM & 2011 & Italy & 47/69 (68.12\%) & M.d (3) & {$[25]$} \\
\hline Pogo BG & 1999 & Italy & 26/69 (37.68\%) & M.d (3) & [29] \\
\hline Wang $Y$ & 1995 & America & 181/465 (38.92\%) & M.d (3) & {$[28]$} \\
\hline Etkind $\mathrm{P}$ & 2000 & America & 27/73 (36.99\%) & M.d (3) & [30] \\
\hline Al Dossary $R$ & 2018 & Saudi Arabia & 6/101 (5.94\%) & M.d (3) & [23] \\
\hline Naccarato AG & 2019 & Italy & 17/56 (30.36\%) & M.d (3) & {$[60]$} \\
\hline Zammarchi F & 2006 & Italy & 15/45 (33.33\%) & M.d (3) & [41] \\
\hline Hachana M & 2008 & Tunisia & 17/122 (13.93\%) & M.d (3) & [43] \\
\hline
\end{tabular}

Studies included for the meta-analysis

M.d: M. domesticus mouse; M.m: M. musculus mouse and M.c: M. castaneus mouse

cellular proto-oncogenes and activate their transcription, which is postulated to be the carcinogenic mechanism of MMTV [70]. Due to the non-specific integration site of MMTV in genes [71], the higher concentration of the virus, it is more likely that the proviral DNA will integrate into the vicinity of the proto-oncogene. In fact, several mammalian oncogenes such as Wnt gene family were discovered just because of their correlation with
MMTV [9]. Therefore, the incidence and latency of breast cancer are proportional to the burden of MMTV [72]. Besides, the env protein also involves in transformation process of mammary epithelial cells mediated by MMTV, because MMTV-induced breast tumor can be reduced by the mutation of the env protein, even the virus load is at high levels [73]. MMTV-LV, containing LTR and env sequences, shares 95\% homology with 


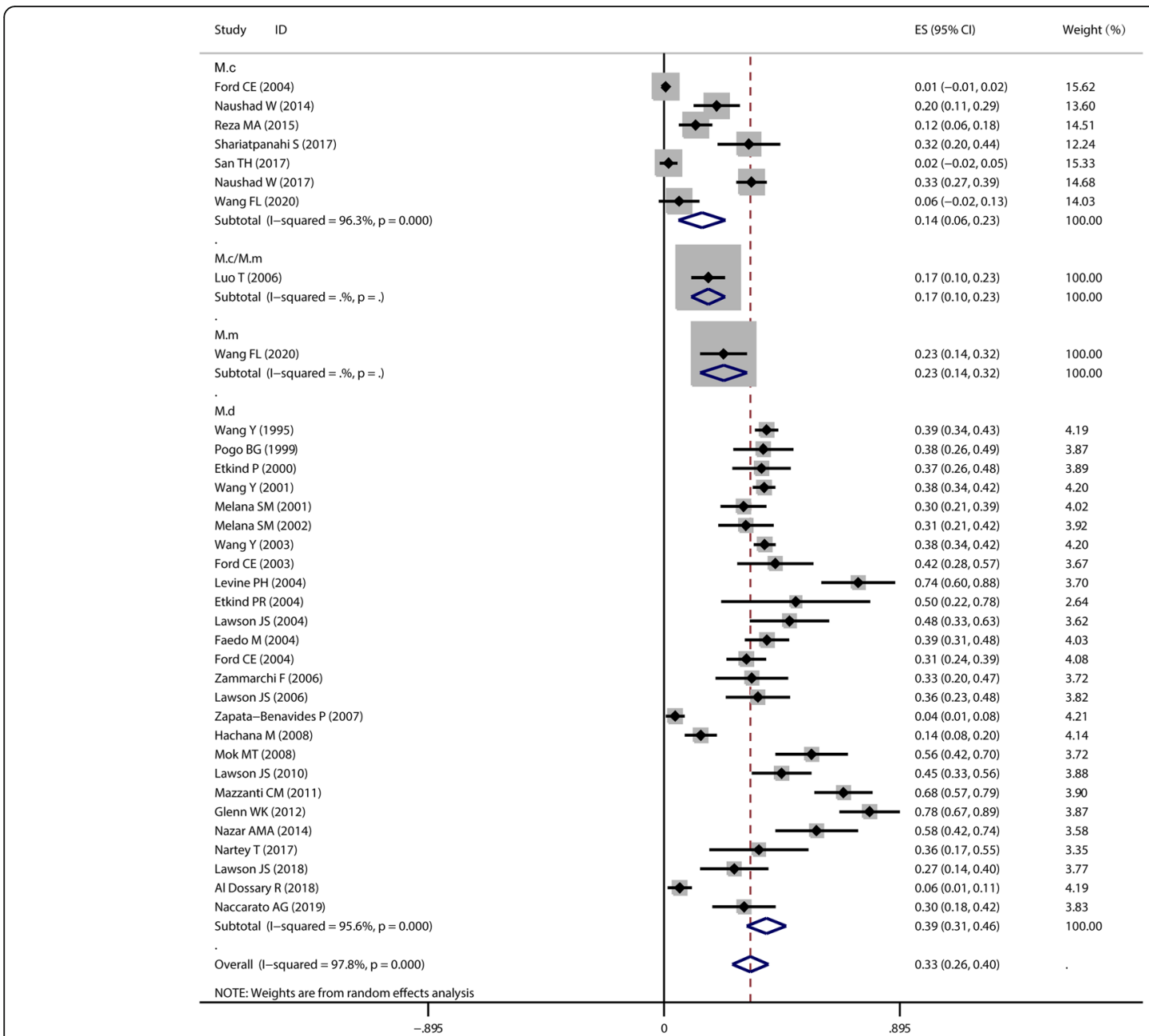

Fig. 5 The meta-analysis of MMTV-LV prevalence in women breast cancer tissue. The data sets were divided in four subgroups (M.c, M.c/M.m, M.m and M.d) and analysed in a random effects model

MMTV and has the potential to express, replicate and integrate into the genome of host cells [74]. MMTV-LV may trigger the occurrence of breast cancer with similar mechanism.

In the analysis of the correlation between prevalence of MMTV-LV and clinicopathological characteristics, we found that the presence of MMTV-like env sequences in breast carcinoma specimens was associated significantly with sample source and HER-2 expression (Table 4).

HER2 is a known proto-oncogene and it is overexpressed in about $30-50 \%$ of human breast cancer [ 75 , 76]. The overexpression of HER-2, predicting a poor prognosis, plays a key role in breast cancer development and metastasis. Thus, HER-2 has become an important target in breast cancer treatment $[77,78]$. In vitro experiments have showed that Epstein-Barr virus infection was related with increased expression and activation of HER2 signaling cascades, which could be blocked by trastuzumab [79]. Our finding suggests that the role of
MMTV-LV in human breast cancer may be also correlated to the HER2 oncogenic pathway, but it remains to be confirmed in further molecular mechanism research.

With regard to sample sources, we discovered the prevalence of MMTV-LV in Chinese breast cancer is correlated with the distribution of house mice. According to the studies reported previously [48, 49], Zhejiang and Hebei, which respectively locate in Southern and Northern China, were distributed with different kind of house mice (M.c and M.m, respectively). The different prevalence of MMTV-LV in Southern and Northern China may due to the different viral burden of MMTV in mice [49].

In order to confirm the association between the prevalence of MMTV-LV in breast cancer tissues and the distribution of house mice worldwide, we then performed a meta-analysis in subgroups and a meta-regression analysis. We found that the MMTV-LV prevalence in breast cancer was increasing from M.c region, M.m region to 


\section{Meta Regression}

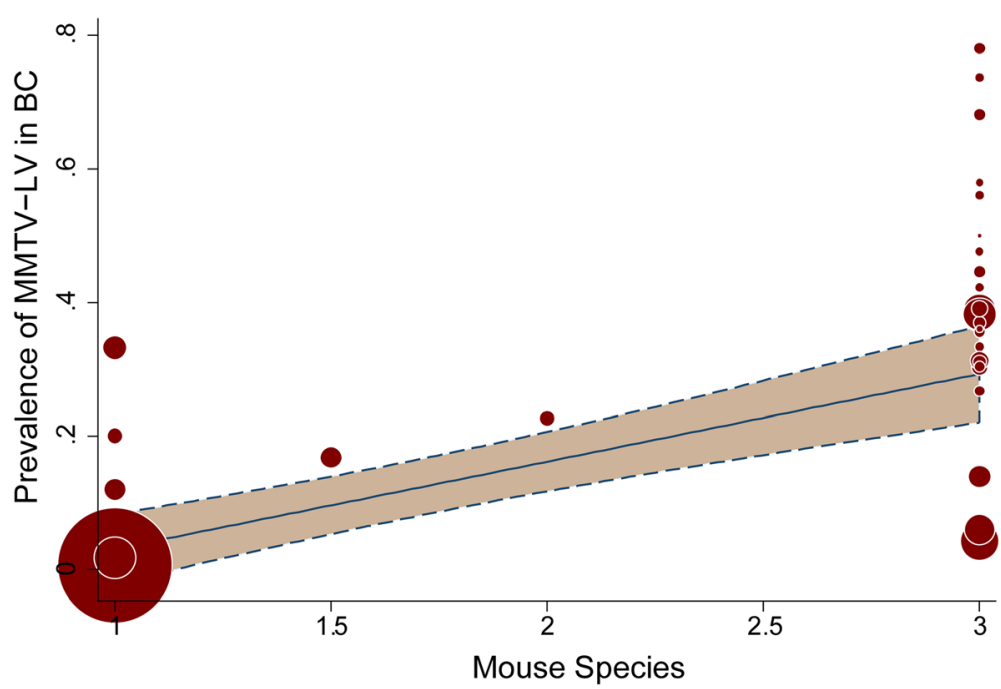

Fig. 6 Meta-regression analysis. In this model, the dependent variable is prevalence of MMTV-LV, while the covariant is the mouse species. X-axis represents different house mice species (1: M.c, 1.5: M.c/M.m, 2: M.m, 3: M.d). Y-axis denotes the prevalence of MMTV-LT in breast cancer in Chinese women

M.d region. The distribution of house mice could explain $27.31 \%$ of the difference in the MMTV-LV prevalence in breast cancer specimens from different regions.

To sum up, the distribution of house mice in the world may partly account for the geographical variation in breast cancer incidence worldwide. Study of Hunter et al. showed that high-fat diet and xeno-oestrogens intake were considered risk factors for breast cancer [80]. However, the diet of circumpolar Inuit is rich in saturated fat and contaminated with high doses of xenooestrogens [81], but the incidence of breast cancer is low [82]. More interestingly, it is generally agreed that environmental changes can lead to an increased risk of breast cancer [83]. When people migrate to areas with higher breast cancer incidence, their risk of breast cancer gradually increases. For instance, the migration of Japanese to the United States [84], and South Asians to Britain [85] demonstrated that the incidence of breast cancer had increased over decades. Among these areas, a remarkable difference is the distribution of M.c, M.m and M.d with different MMTV burden, so it may be the crucial environmental factor that explains the geographic variation in human breast cancer incidence.

\section{Conclusion}

The results of this study suggest that MMTV-LV infection may increase the risk of breast cancer. Besides, MMTV-LV prevalence is significantly associated with sample source and HER2 expression, but there is no significant correlation between MMTV-LV prevalence and age of patients, histological grade, histological type, lymph node involvement, tumor position or expression of ER and PR in breast cancer tissues. In the metaanalysis, we find that MMTV-LV prevalence in breast cancer is dependent on the distribution of M.c, M.m and M.d. The results of this study support the zoonotic hypothesis that MMTV-LV is transferred from domestic mice to human and is a crucial risk factor for human breast cancer. These findings may provide a potential avenue in breast cancer prevention, diagnosis and treatment.

\section{Abbreviations}

MMTV-LV: Mouse Mammary Tumor Virus-Like Virus; ER: Estrogen receptor; PR: Progesterone receptor; M. d: M. domesticus mouse; M.m: M. musculus mouse; M.c: M.castaneus mouse

\section{Supplementary Information}

The online version contains supplementary material available at https://doi. org/10.1186/s13027-021-00383-2.

\section{Additional file 1.}

\section{Acknowledgements}

We would like to acknowledge the guidance of Fajun Xie in clinical data analysis and meta-analysis. We also thank all the participants in our study, especially the pathologists who provided the samples in our study.

\section{Authors' contributions}

$\mathrm{HJ}, \mathrm{QS}, \mathrm{FW}$ and $\mathrm{XW}$ contributed to design the study. $X Z, J L, Y Y$ and $Y L$ collected the samples and did the experimental work. FW and MY analysed the clinical data and did the meta-analysis. FW wrote the manuscript. All the authors reviewed, critically revised, and approved the manuscript. 


\section{Funding}

This research was financially supported by National Natural Science Foundation of China (81801939), Health Commission of Zhejiang Province (2019KY093) and China Scholarship Council (201906325005).

\section{Availability of data and materials}

All data supporting the findings of this study are available with the corresponding authors.

\section{Declarations}

\section{Ethics approval and consent to participate}

Ethics approval was obtained through Medical Ethics Committee of the Second People's Hospital of Jiande (clearance number: Jdey070817). Due to the fact that the project was a retrospective study and remaining-clinical samples were used, informed consent was exempted (Supplementary Fig. 1).

\section{Consent for publication}

Publication consent was obtained from all authors.

\section{Competing interests}

The authors declare they have no competing interests.

\begin{abstract}
Author details
'Department of Surgical Oncology, The Children's Hospital, Zhejiang University School of Medicine, National Clinical Research Center for Child Health, Binsheng Road 3333, Hangzhou 310052, China. ${ }^{2}$ Electron Microscope Room, Medical School of Hebei North University, Zhangjiakou, China. ${ }^{3}$ Department of Medical Oncology, the Second People's Hospital of Jande, Hangzhou, China. ${ }^{4}$ Department of Obstetrics and Gynecology, the Women's Hospital, School of Medicine, Zhejiang University, Hangzhou, China. ${ }^{5}$ Laboratory of Cancer Biology, Department of Medical Oncology, Key lab of Biotherapy in Zhejiang, Sir Run Run Shaw Hospital, School of Medicine, Zhejiang University, East Qingchun Road 3, Hangzhou 310000, China. ${ }^{6}$ Department of Cardiothoracic Surgery, The Children's Hospital, Zhejiang University School of Medicine, National Clinical Research Center for Child Health, Binsheng Road 3333, Hangzhou 310052, China.
\end{abstract}

\section{Received: 7 February 2021 Accepted: 7 June 2021}

\section{Published online: 26 June 2021}

\section{References}

1. Masjedi S, Zwiebel LJ, Giorgio TD. Olfactory receptor gene abundance in invasive breast carcinoma. Sci Rep. 2019;9:13736 PMID:31551495.

2. Monk JM, Turk HF, Liddle DM, De Boer AA, Power KA, Ma DWL, et al. n-3 polyunsaturated fatty acids and mechanisms to mitigate inflammatory paracrine signaling in obesity-associated breast cancer. Nutrients. 2014;6: 4760-93 PMID:25360510

3. Bille C, Winther JF, Bautz A, Murray JC, Olsen J, Christensen K. Cancer risk in persons with oral cleft--a population-based study of 8,093 cases. Am. J. Epidemiol. 2005:161:1047-55 PMID:15901625.

4. Holmes MD, Wang J, Hankinson SE, Tamimi RM, Chen WY. Protein Intake and Breast Cancer Survival in the Nurses' Health Study. J Clin Oncol. 2017; 35:325-33 PMID:28095274

5. Nones K, Johnson J, Newell F, Patch AM, Thorne H, Kazakoff SH, et al. Whole-genome sequencing reveals clinically relevant insights into the aetiology of familial breast cancers. Ann Oncol. 2019;30:1071-9 PMID: 31090900.

6. Raj U, Aier I, Semwal R, Varadwaj PK. Identification of novel dysregulated key genes in Breast cancer through high throughput ChIP-Seq data analysis. Sci Rep. 2017;7:3229 PMID:28607444.

7. Cancer CGoHFiB. Familial breast cancer: collaborative reanalysis of individual data from 52 epidemiological studies including 58,209 women with breast cancer and 101,986 women without the disease. Lancet. 2001;358:1389-99 PMID:11705483

8. Dumitrescu RG, Cotarla I. Understanding breast cancer risk -- where do we stand in 2005? J Cell Mol Med. 2005;9:208-21 PMID:15784178.

9. Callahan R, Smith GH. MMTV-induced mammary tumorigenesis: gene discovery, progression to malignancy and cellular pathways. Oncogene. 2000;19:992-1001 PMID:10713682.
10. Bittner JJ. Some possible effects of nursing on the mammary gland tumor incidence in mice. Science. 1936:84:162 PMID:17793252.

11. Callahan R, Benveniste RE, Sherr CJ, Schidlovsky G, Todaro GJ. A new class of genetically transmitted retravirus isolated from Mus cervicolor. Proc Natl Acad Sci U S A. 1976;73:3579-83 PMID:62362.

12. Benveniste RE, Callahan R, Sherr CJ, Chapman V, Todaro GJ. Two distinct endogenous type $C$ viruses isolated from the asian rodent Mus cervicolor: conservation of virogene sequences in related rodent species. J Virol. 1977; 21:849-62 PMID:66330.

13. Nartey T, Moran H, Marin T, Arcaro KF, Anderton DL, Etkind P, et al. Human Mammary Tumor Virus (HMTV) sequences in human milk. Infect Agent Cancer. 2014;9:20 PMID:25120582.

14. Müller M, Grossman H. An antigen in human breast cancer sera related to the murine mammary tumour virus. Nat New Biol. 1972;237:116-7 PMID: 4338143.

15. Lasfargues EY, Coutinho WG, Dion AS. A human breast tumor cell line (BT474) that supports mouse mammary tumor virus replication. In Vitro. 1979; 15:723-9 PMID:94035.

16. Melana SM, Holland JF, Pogo BGT. Search for mouse mammary tumor viruslike env sequences in cancer and normal breast from the same individuals. Clin Cancer Res. 2001:7:283-4 PMID:11234880.

17. Ford CE, Faedo M, Crouch R, Lawson JS, Rawlinson WD. Progression from normal breast pathology to breast cancer is associated with increasing prevalence of mouse mammary tumor virus-like sequences in men and women. Cancer Res. 2004;64:4755-9 PMID:15256443.

18. Holland JF, Pogo BG. Mouse mammary tumor virus-like viral infection and human breast cancer. Clin Cancer Res. 2004;10:5647-9 PMID:15355888.

19. Mok MT, Lawson JS, lacopetta BJ, Whitaker NJ. Mouse mammary tumor virus-like env sequences in human breast cancer. Int J Cancer. 2008;122: 2864-70 PMID:18348144.

20. Naushad W, Bin Rahat T, Gomez MK, Ashiq MT, Younas M, Sadia H. Detection and identification of mouse mammary tumor virus-like DNA sequences in blood and breast tissues of breast cancer patients. Tumor Biol. 2014:35:8077-86 PMID:24839004.

21. Lawson JS, Mazzanti C, Civita P, Menicagli M, Ngan CC, Whitaker NJ, et al. Association of Mouse Mammary Tumor Virus With Human Breast Cancer: Histology, Immunohistochemistry and Polymerase Chain Reaction Analyses. Front Oncol. 2018:8:141 PMID:29868468.

22. Naushad W, Surriya O, Sadia H. Prevalence of EBV, HPV and MMTV in Pakistani breast cancer patients: A possible etiological role of viruses in breast cancer. Infect Genet Evol. 2017;54:230-7 PMID:28705719.

23. Al Dossary R, Alkharsah KR, Kussaibi H. Prevalence of Mouse Mammary Tumor Virus (MMTV)-like sequences in human breast cancer tissues and adjacent normal breast tissues in Saudi Arabia. BMC Cancer. 2018;18:170 PMID:29426297.

24. Glenn WK, Heng B, Delprado W, lacopetta B, Whitaker NJ, Lawson JS. EpsteinBarr virus, human papillomavirus and mouse mammary tumour virus as multiple viruses in breast cancer. PLoS One. 2012;7:e48788 PMID:23183846.

25. Mazzanti CM, Al Hamad M, Fanelli G, Scatena C, Zammarchi F, Zavaglia K, et al. A mouse mammary tumor virus env-like exogenous sequence is strictly related to progression of human sporadic breast carcinoma. Am J Pathol. 2011;179:2083-90 PMID:21854742.

26. Wang F, Hou J, Shen Q, Yue Y, Xie F, Wang X, et al. Mouse mammary tumor virus-like virus infection and the risk of human breast cancer: a metaanalysis. Am J Transl Res. 2014;6:248-66 PMID:24936218.

27. Naccarato AG, Lessi F, Zavaglia K, Scatena C, Al Hamad MA, Aretini P, et al. Mouse mammary tumor virus (MMTV) - like exogenous sequences are associated with sporadic but not hereditary human breast carcinoma. Aging (Albany NY). 2019;11:7236-41 PMID:31518337.

28. Wang Y, Holland JF, Bleiweiss IJ, Melana S, Liu X, Pelisson I, et al. Detection of mammary tumor virus env gene-like sequences in human breast cancer. Cancer Res. 1995;55:5173-9 PMID:7585568.

29. Pogo BG, Melana SM, Holland JF, Mandeli JF, Pilotti S, Casalini P, et al. Sequences homologous to the mouse mammary tumor virus env gene in human breast carcinoma correlate with overexpression of laminin receptor. Clin Cancer Res. 1999;5:2108-11 PMID:10473094

30. Etkind P, Du J, Khan A, Pillitteri J, Wiernik PH. Mouse mammary tumor viruslike ENV gene sequences in human breast tumors and in a lymphoma of a breast cancer patient. Clin Cancer Res. 2000;6:1273-8 PMID:10778951.

31. Wang Y, Pelisson I, Melana SM, Go V, Holland JF, Pogo BG. MMTV-like env gene sequences in human breast cancer. Arch Virol. 2001;146:171-80 PMID: 11266212 . 
32. Wang Y, Pelisson I, Melana SM, Holland JF, Pogo BG. Detection of MMTV-like LTR and LTR-env gene sequences in human breast cancer. Int J Oncol. 2001; 18:1041-4 PMID:11295054.

33. Melana SM, Picconi MA, Rossi C, Mural J, Alonio LV, Teyssié A, et al. Detection of murine mammary tumor virus (MMTV) env gene-like sequences in breast cancer from Argentine patients. Medicina (B Aires). 2002;62:323-7 PMID:12325488.

34. Ford CE, Tran D, Deng Y, Ta VT, Rawlinson WD, Lawson JS. Mouse mammary tumor virus-like gene sequences in breast tumors of Australian and Vietnamese women. Clin Cancer Res. 2003;9:1118-20 PMID:12631616.

35. Wang Y, Melana SM, Baker B, Bleiweiss I, Fernandez-Cobo M, Mandeli JF, et al. High prevalence of MMTV-like env gene sequences in gestational breast cancer. Med Oncol. 2003;20:233-6 PMID:14514972.

36. Etkind PR, Stewart AF, Dorai T, Purcell DJ, Wiernik PH. Clonal isolation of different strains of mouse mammary tumor virus-like DNA sequences from both the breast tumors and non-Hodgkin's lymphomas of individual patients diagnosed with both malignancies. Clin Cancer Res. 2004;10:565664 PMID:15355890.

37. Faedo M, Ford CE, Mehta R, Blazek K, Rawlinson WD. Mouse mammary tumor-like virus is associated with p53 nuclear accumulation and progesterone receptor positivity but not estrogen positivity in human female breast cancer. Clin Cancer Res. 2004;10:4417-9 PMID:15240531.

38. Lawson JS, Tran DD, Ford C, Rawlinson WD. Elevated expression of the tumor suppressing protein p53 is associated with the presence of mouse mammary tumor-like env gene sequences (MMTV-like) in human breast cancer. Breast Cancer Res Treat. 2004;87:13-7 PMID:15377846.

39. Levine PH, Pogo BGT, Klouj A, Coronel S, Woodson K, Melana SM, et al. Increasing evidence for a human breast carcinoma virus with geographic differences. Cancer. 2004;101:721-6 PMID:15305401.

40. Lawson JS, Tran DD, Carpenter E, Ford CE, Rawlinson WD, Whitaker NJ, et al. Presence of mouse mammary tumour-like virus gene sequences may be associated with morphology of specific human breast cancer. J Clin Pathol. 2006;59:1287-92 PMID:16698952.

41. Zammarchi F, Pistello M, Piersigilli A, Murr R, Di Cristofano C, Naccarato AG, et al. MMTV-like sequences in human breast cancer: a fluorescent PCR/laser microdissection approach. J Pathol. 2006;209:436-44 PMID:16710841.

42. Zapata-Benavides P, Saavedra-Alonso S, Zamora-Avila D, Vargas-Rodarte C, BarreraRodriguez R, Salinas-Silva J, et al. Mouse mammary tumor virus-like gene sequences in breast cancer samples of Mexican women. Intervirology. 2007;50:402-7 PMID:17975321.

43. Hachana M, Trimeche M, Ziadi S, Amara K, Gaddas N, Mokni M, et al. Prevalence and characteristics of the MMTV-like associated breast carcinomas in Tunisia. Cancer Lett. 2008;271:222-30 PMID:18639977.

44. Lawson JS, Glenn WK, Salmons B, Ye Y, Heng B, Moody P, et al. Mouse mammary tumor virus-like sequences in human breast cancer. Cancer Res. 2010;70:3576-85 PMID:20388779.

45. Park DJ, Southey MC, Giles GG, Hopper JL. No evidence of MMTV-like env sequences in specimens from the Australian Breast Cancer Family Study. Breast Cancer Res Treat. 2011;125:229-35 PMID:20512660.

46. Luo T, Wu XT, Zhang MM, Qian K. Study of mouse mammary tumor viruslike gene sequences expressing in breast tumors of Chinese women. Sichuan Da Xue Xue Bao Yi Xue Ban. 2006;37:844-6 851. PMID:17236577.

47. San TH, Fujisawa M, Fushimi S, Yoshimura T, Ohara T, Soe L, et al. Low prevalence of human mammary tumor virus (HMTV) in breast cancer patients from Myanmar. Infect Agent Cancer. 2017;12:20 PMID:28413435.

48. Sage RD, Atchley WR, Capanna E. House Mice as Models in Systematic Biology. Syst. Biol. 1993:523-61. https://doi.org/10.2307/2992487.

49. Stewart $\mathrm{TH}$, Sage RD, Stewart AF, Cameron DW. Breast cancer incidence highest in the range of one species of house mouse, Mus domesticus. $\mathrm{Br} J$ Cancer. 2000:82:446-51 PMID:10646903.

50. Tavassoli FA, Devilee P. Pathology \& genetics: tumours of the breast and female genital organs: larc; 2003.

51. Elston CW, Ellis IO. Pathological prognostic factors in breast cancer. I. The value of histological grade in breast cancer: experience from a large study with long-term follow-up. Histopathology. 1991;19:403-10 PMID:1757079.

52. Chung J, Noh H, Park KH, Choi E, Han A. Longer survival in patients with breast cancer with cyclin d1 over-expression after tumor recurrence: longer, but occupied with disease. J Breast Cancer. 2014;17:47-53 PMID:24744797.

53. Mant C, Gillett C, D'Arrigo C, Cason J. Human murine mammary tumour virus-like agents are genetically distinct from endogenous retroviruses and are not detectable in breast cancer cell lines or biopsies. Virology. 2004;318: 393-404 PMID:14972564.
54. Glenn WK, Lawson JS, Whitaker NJ. Mouse mammary tumour-like virus gene sequences and specific breast cancer morphology. J Clin Pathol. 2007;60: 1071 PMID:17158634.

55. Reza MA, Reza MH, Mahdiyeh L, Mehdi F, Hamid ZN. Evaluation Frequency of Merkel Cell Polyoma, Epstein-Barr and Mouse Mammary Tumor Viruses in Patients with Breast Cancer in Kerman, Southeast of Iran. Asian Pac J Cancer Prev. 2015;16:7351-7 PMID:26514536.

56. Ford CE, Faedo M, Rawlinson WD. Mouse mammary tumor virus-like RNA transcripts and DNA are found in affected cells of human breast cancer. Clin Cancer Res. 2004;10:7284-9 PMID:15534103.

57. Shariatpanahi S, Farahani N, Salehi AR, Salehi R. High prevalence of mouse mammary tumor virus-like gene sequences in breast cancer samples of Iranian women. Nucleosides Nucleotides Nucleic Acids. 2017:36:621-30 PMID:29185860.

58. Nartey T, Mazzanti CM, Melana S, Glenn WK, Bevilacqua G, Holland JF, et al. Mouse mammary tumor-like virus (MMTV) is present in human breast tissue before development of virally associated breast cancer. Infect Agent Cancer. 2017;12:1 PMID:28053656.

59. Tarish HR, Aljanabi A, Nazar AMA. Detection Of Mouse Mammary Tumor Virus-Like Sequence (MMTV-Like Sequence) In The Breast Cancer Of Iraqi Women Samples By Nested PCR. Kufa J Nurs Sci. 2014;4:134-43.

60. Naccarato AG, Lessi F, Zavaglia K, Scatena C, Al Hamad MA, Aretini P, et al. Mouse mammary tumor virus (MMTV)-like exogenous sequences are associated with sporadic but not hereditary human breast carcinoma. Aging. 2019;11:7236 PMID:31518337.

61. DerSimonian R, Kacker R. Random-effects model for meta-analysis of clinical trials: an update. Contemp Clin Trials. 2007;28:105-14 PMID:16807131.

62. Egger M, Davey Smith G, Schneider M, Minder C. Bias in meta-analysis detected by a simple, graphical test. BMJ. 1997;315:629-34 PMID:9310563.

63. Ohno T, Mesa-Tejada R, Keydar I, Ramanarayanan M, Bausch J, Spiegelman $\mathrm{S}$. Human breast carcinoma antigen is immunologically related to the polypeptide of the group-specific glycoprotein of mouse mammary tumor virus. Proc Natl Acad Sci U S A. 1979;76:2460-4 PMID:88056.

64. Witkin SS, Sarkar NH, Kinne DW, Good RA, Day NK. Antibodies reactive with the mouse mammary tumor virus in sera of breast cancer patients. Int J Cancer. 1980;25:721-5 PMID:14768700.

65. Moore DH, Charney J, Kramarsky B, Lasfargues EY, Sarkar NH, Brennan MJ, et al. Search for a human breast cancer virus. Nature. 1971;229:611-4 PMID:4925461.

66. May FE, Westley BR, Rochefort H, Buetti E, Diggelmann H. Mouse mammary tumour virus related sequences are present in human DNA. Nucleic Acids Res. 1983;11:4127-39 PMID:6306576.

67. Szabo S, Haislip AM, Garry RF. Of mice, cats, and men: is human breast cancer a zoonosis? Microsc Res Tech. 2005;68:197-208 PMID:16276516.

68. Mazzanti CM, Lessi F, Armogida I, Zavaglia K, Franceschi S, Al Hamad M, et al. Human saliva as route of inter-human infection for mouse mammary tumor virus. Oncotarget. 2015;6:18355-63 PMID:26214095.

69. Etkind PR, Stewart AF, Wiernik PH. Mouse mammary tumor virus (MMTV)-like DNA sequences in the breast tumors of father, mother, and daughter. Infect Agent Cancer. 2008:3:2 PMID:18307792.

70. Popken-Harris P, Kirchhof N, Harrison B, Harris LF. Gene expression array analyses predict increased proto-oncogene expression in MMTV induced mammary tumors. Virus Res. 2006;119:177-86 PMID:16469401.

71. Faschinger A, Rouault F, Sollner J, Lukas A, Salmons B, Gunzburg WH, et al. Mouse mammary tumor virus integration site selection in human and mouse genomes. J Virol. 2008;82:1360-7 PMID:18032509.

72. Golovkina TV, Prescott JA, Ross SR. Mouse mammary tumor virus-induced tumorigenesis in sag transgenic mice: a laboratory model of natural selection. J Virol. 1993;67:7690-4 PMID:8230492.

73. Ross SR, Schmidt JW, Katz E, Cappelli L, Hultine S, Gimotty P, et al. An immunoreceptor tyrosine activation motif in the mouse mammary tumor virus envelope protein plays a role in virus-induced mammary tumors. J Virol. 2006;80:9000-8 PMID:16940512.

74. Liu B, Wang Y, Melana SM, Pelisson I, Najfeld V, Holland JF, et al. Identification of a proviral structure in human breast cancer. Cancer Res. 2001;61:1754-9 PMID:11245493.

75. Slamon DJ, Godolphin W, Jones LA, Holt JA, Wong SG, Keith DE, et al. Studies of the HER-2/neu proto-oncogene in human breast and ovarian cancer. Science. 1989;244:707-12 PMID:2470152.

76. Lee HY, Shin IS, Rim CH. Benefits of adjuvant treatment including trastuzumab in HER2-positive pT1a-bNOMO breast cancer: a systematic review and meta-analysis. Ann Transl Med. 2020;8:187 PMID:32309334. 
77. Wu Y, Yan B, Xu W, Guo L, Wang Z, Li G, et al. Compound C enhances the anticancer effect of aspirin in HER-2-positive breast cancer by regulating lipid metabolism in an AMPK-independent pathway. Int J Biol Sci. 2020;16: 583-97 PMID:32025207.

78. Yu D, Hung MC. Overexpression of ErbB2 in cancer and ErbB2-targeting strategies. Oncogene. 2000;19:6115-21 PMID:11156524.

79. Lin JH, Tsai CH, Chu JS, Chen JY, Takada K, Shew JY. Dysregulation of HER2/ HER3 signaling axis in Epstein-Barr virus-infected breast carcinoma cells. J Virol. 2007:81:5705-13 PMID:17376931.

80. Hunter DJ, Spiegelman D, Adami HO, Beeson L, van den Brandt PA, Folsom $A R$, et al. Cohort studies of fat intake and the risk of breast cancer--a pooled analysis. N Engl J Med. 1996;334:356-61 PMID:8538706.

81. Ayotte P, Dewailly E, Ryan JJ, Bruneau S, Lebel G. PCBs and dioxin-like compounds in plasma of adult Inuit living in Nunavik (Arctic Quebec). Chemosphere. 1997:34:1459-68 PMID:9134679.

82. Miller AB, Gaudette LA. Breast cancer in Circumpolar Inuit 1969-1988. Acta Oncol. 1996;35:577-80 PMID:8813064.

83. Hunter DJ, Hankinson SE, Laden F, Colditz GA, Manson JE, Willett WC, et al. Plasma organochlorine levels and the risk of breast cancer. N Engl J Med. 1997;337:1253-8 PMID:9345073.

84. Ziegler RG, Hoover RN, Pike MC, Hildesheim A, Nomura AM, West DW, et al. Migration patterns and breast cancer risk in Asian-American women. J Natl Cancer Inst. 1993:85:1819-27 PMID:8230262.

85. Winter H, Cheng KK, Cummins C, Maric R, Silcocks P, Varghese C. Cancer incidence in the south Asian population of England (1990-92). Br J Cancer. 1999:79:645-54 PMID:10027344

\section{Publisher's Note}

Springer Nature remains neutral with regard to jurisdictional claims in published maps and institutional affiliations.

Ready to submit your research? Choose BMC and benefit from:

- fast, convenient online submission

- thorough peer review by experienced researchers in your field

- rapid publication on acceptance

- support for research data, including large and complex data types

- gold Open Access which fosters wider collaboration and increased citations

- maximum visibility for your research: over $100 \mathrm{M}$ website views per year

At $\mathrm{BMC}$, research is always in progress.

Learn more biomedcentral.com/submissions 